7. Reprod. Fert. (1970) 22, 515-531

\title{
THE EFFECT OF DOSE LEVEL OF INTRAVAGINAL PROGESTAGEN ON SPERM TRANSPORT, FERTILIZATION AND LAMBING IN THE CYCLIC MERINO EWE
}

\author{
A. J. ALLISON AND T. J. ROBINSON \\ Department of Animal Husbandry, University of Sydney, Sydney, N.S.W. 2006, \\ Australia \\ (Received 12th August 1969)
}

Summary. The numbers of spermatozoa recovered from the Fallopian tubes $24 \mathrm{hr}$ after insemination, fertilization rate and lambing were measured in one group of 120 normal cyclic ewes and in three groups of 120 animals which had been synchronized with intravaginal sponges impregnated with 10,30 or $90 \mathrm{mg}$ Gronolone (Searle). Half of each group received 500 i.u. PMsG. Results were as follows:

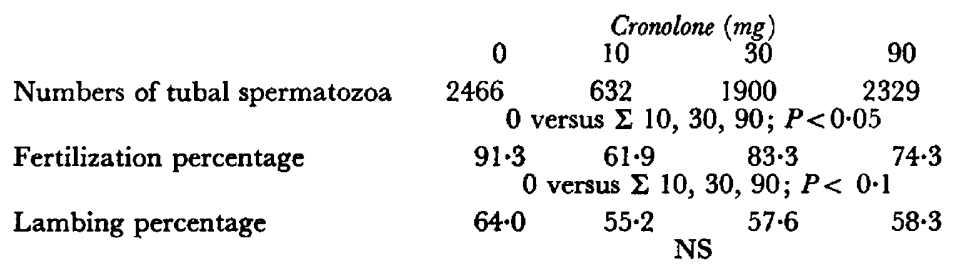

PMSG had no apparent effect on any one of the three parameters. Increasing dose of progestagen significantly increased the incidence of oestrus and was associated with an increasing ovarian response to PMSG. There was no evidence that embryonic mortality was greater in progestagen-treated than in untreated ewes.

Considering all parameters of fertility, ewes treated with intravaginal sponges containing $10 \mathrm{mg}$ Cronolone yielded the fewest spermatozoa, the lowest number and percentage of fertilized eggs and the lowest percentage of lambing ewes.

\section{INTRODUCTION}

Failure of fertilization is a major cause of sub-fertility in the ewe treated with progestagen-impregnated sponges for the control of the time of oestrus (Moore, Quinlivan, Robinson \& Smith, 1967). Quinlivan \& Robinson (1967, 1969) demonstrated differences between 'normally cyclic' and treated ewes in the pattern of sperm transport and survival, sufficiently large to account for the observed differences in fertility.

Further, there is a relationship between dose of progestagen and fertility. 
Robinson, Salamon, Holst \& Smith (1967), Robinson \& Smith (1967) and Robinson, Quinlivan \& Baxter (1968) have found increasing fertility with increasing doses of progestagen (SG-9880; Cronolone, Searle), impregnated in intravaginal sponges, over the dose range: 5 to $40 \mathrm{mg}$.

Consequently, an experiment was conducted from February to March, 1968, to investigate the relationships between Cronolone treatment at three dose levels and the numbers of spermatozoa recovered from the Fallopian tubes 24 $\mathrm{hr}$ after insemination, the number of ewes fertilized and the number which lambed.

\section{MATERIALS AND METHODS}

\section{Experimental design}

Four hundred and eighty Merino ewes (4 years old) were incorporated into a $4 \times 2$ factorial experiment in which all the animals were used for oestrous data $(\mathrm{n}=60)$. They were further subdivided into three end-point sub-groups:

Treatments: Dose of Cronolone- 0 (Control), 10, 30, $90 \mathrm{mg}$. Dose of PMSG $\quad-0,500$ i.u.

For oestrous data: $4 \times 2 ; \mathrm{n}=60, \mathrm{~N}=480$.

End-points: (a) Recovery of spermatozoa $24 \mathrm{hr}$ after insemination.

(b) Recovery of ova $48 \mathrm{hr}$ after insemination.

(c) Lambing.

For each end point: $4 \times 2 ; n^{\prime}=20, N^{\prime}=160$.

Not all ewes exhibited oestrus so that only 385 were inseminated, of which four were lost so that the final numbers available for the three end-points were (a) 130, (b) 128, and (c) 123.

For convenience, the oestrous cycles of the 120 ewes which were not treated with Cronolone immediately before insemination had been synchronized one cycle (16 days) before with intravaginal sponges impregnated with $30 \mathrm{mg}$ Cronolone. Previous experience has shown that fertility is normal at the second oestrus following synchronization (Robinson, 1967).

\section{Hormone administration}

The three doses of Cronolone were incorporated into the sponges by placing the appropriate amount in a $50-\mathrm{ml}$ beaker in $5 \mathrm{ml}$ ethanol and compressing the sponge in the solution to ensure even distribution. Sponges were then air dried at ambient temperature and were dusted with penicillin powder before insertion.

The PMSG (Organon, G. D. Searle) was injected intramuscularly (i.m.) in $2 \mathrm{ml}$ distilled water to half the ewes 1 day before sponge withdrawal in the 10-, 30and $90-\mathrm{mg}$ treatments and 16 days after withdrawal in the control animals.

\section{Conduct of the experiment}

Management. The 480 ewes were randomly allocated to their respective groups, starting on 2nd February. Sponges were inserted 33 to 35 days before anticipated insemination of the $0 \mathrm{mg}$ Cronolone treatment and 17 to 19 days before insemination of the 10-, 30- and $90-\mathrm{mg}$ treatments. 
Sponge insertions and withdrawals were spaced so that inseminations and the intensive phase of the experiment involving recovery of spermatozoa and ova were spread over a 14-day period.

In addition, sponges were inserted in separate animals for $2,4,6,8,10,12$ and 14 days, respectively, in order to express quantitatively the release characteristics for the three doses. Ten sponges were inserted for each time interval. Analysis of residual hormone was carried out, using a method similar to that described by Morgan, Lack \& Robinson (1967).

All sponges were labelled on withdrawal and were air dried for analysis of residual hormone. Ewes were run with twelve vasectomized rams fitted with 'Sire-sine' harnesses and crayons (Radford, Watson \& Wood, 1960), which were replaced by a fresh group midway through the experiment.

Artificial insemination. Ewes were inspected for oestrus twice daily at 06.00 and 17.00 hours. They were inseminated as soon as possible using 0.07 to $0.10 \mathrm{ml}$ of undiluted semen.

Collection of semen was by artificial vagina and the ejaculates of five or six rams were pooled. Each ejaculate was assessed visually and only semen of a high density and motility rating (Emmens \& Robinson, 1962) was used. During any one inseminating period, a continual check was kept on the motility of the pooled ejaculate. Numbers inseminated ranged from 310 to $400\left(\times 10^{6}\right)$ and all ewes were inseminated within $1 \mathrm{hr}$ of semen collection.

Following insemination, ewes from which spermatozoa and ova were to be recovered were run in a yard adjacent to the shed where they were undisturbed until laparotomy. Lambing ewes were transferred to a nearby paddock once daily.

Recovery of spermatozoa. Following laparotomy under sodium pentobarbitone (Nembutal, Abbott) anaesthesia, each Fallopian tube was cannulated with a $10-$ to $15-\mathrm{cm}$ length of polythene tubing (o.d. $2 \mathrm{~mm}$, i.d. $1 \mathrm{~mm}$ ). A blunt, 22gauge needle was inserted just through the utero-tubal junction and each tube was flushed with $2 \mathrm{ml}$ of $0.9 \%$ sterile saline by running $1 \mathrm{ml}$ of saline through the tube, then approximately $2 \mathrm{ml}$ of air, followed by the remaining 1 $\mathrm{ml}$ of flushing fluid. Each tubal flushing was directed through the cannula into a labelled 4-ml glass vial, which was immediately frozen at $-10^{\circ} \mathrm{C}$.

Thoroughly cleansed and re-sterilized instruments were used for each animal and the hands of the operator and his assistant were meticulously washed before and after manipulation of each tract.

Examination of flushings for spermatozoa. All samples, except those from Fallopian tubes proximal to an ovary with a recent corpus luteum, were stained by adding four drops of eosin B-fast green FCF stain (Hackett \& Macpherson, 1965) following thawing. After thorough mixing, the sample was distributed evenly on four slides. Two strips of vaseline, approximately $35 \mathrm{~mm}$ apart, were placed across the width of each slide. These served to pillar the $20 \times 40 \mathrm{~mm}$ coverslip and also prevented the spread of the sample along the slide during distribution. Slides were allowed to settle for approximately $30 \mathrm{~min}$, when the numbers of spermatozoa in one lengthwise traverse were counted on each slide (magnification, $\times 450$ ). Each traverse represented 1/50th of the area of each slide so that the number counted in a single traverse of each of four slides $\times 50$ gave an esti- 
mate of the total number of spermatozoa recovered from each Fallopian tube. Those samples in which no spermatozoa were found were classed as containing less than fifty spermatozoa.

Those samples flushed from Fallopian tubes proximal to an ovary with a recent corpus luteum were distributed unstained on four slides and examined under a dissecting microscope at $\times 20$ magnification for the presence of ova. After removal of the ovum for subsequent examination, one drop of stain was added to each slide and was evenly mixed with the end of a Pasteur pipette. A $20-\times 40-\mathrm{mm}$ coverslip was carefully lowered on to the sample and counting was carried out as previously detailed.

Analysis of variance was conducted on the actual numbers counted (plus 2 to deal with zero values) after $\log$ transformation using standard statistical programmes on the CSIRO CDC-3600 computer.

Recovery and examination of ova. The reproductive tracts were exposed by laparotomy under Nembutal anaesthesia approximately $48 \mathrm{hr}$ after insemination. The Fallopian tubes were flushed with sterile saline in the manner described by Hunter, Adams \& Rowson (1955) and the ova recovered.

Ova were isolated from the flushing medium and were mounted and slightly compressed between a glass slide and a coverslip held apart by thin strips of vaseline (Dziuk, 1965). The ova were examined first under bright field and phase contrast at $\times 400$ magnification, as fresh whole mounts. Data recorded were: number of spermatozoa on the zona pellucida, polar bodies, cell stage and the presence of fragments. Ova were then fixed in $12.5 \%$ acetic alcohol for 24 $\mathrm{hr}$, stained and re-examined. Single cell ova were classified as unfertilized or fertilized and their stage of fertilization-late pronucleate, prophase, anaphase, telophase-was recorded. Nuclear aberrations were also recorded. Cleaved ova were examined and the number of anucleate cells was recorded.

Examination of ovaries. The ovaries of all ewes subjected to laparotomy at $24 \mathrm{hr}$ or $48 \mathrm{hr}$ after insemination were examined for recent ovulations or large definitive follicles $(>5 \mathrm{~mm}$ ). In addition, thirteen ewes, untreated with progestagen and which did not exhibit oestrus, were subjected to laparotomy 7 or 8 days after the expected date of oestrus to determine the incidence of 'silent' oestrus.

Observations on lambing performance. One month before lambing, the identification number of each ewe was branded on the flank with 'Siromark' sheep-branding fluid. During lambing, the flock was examined daily. Newly-born lambs were caught and marked and the identification number of their dams was recorded.

\section{RESULTS}

Dose of Cronolone absorbed

The mean residual Cronolone estimated in sponges after withdrawal was $1 \cdot 3 \pm 0 \cdot 4,5 \cdot 2 \pm 1 \cdot 4$ and $36 \cdot 6 \pm 6 \cdot 1 \mathrm{mg}$ for the $10-, 30$ - and $90-\mathrm{mg}$ doses, so that means of $8.7,24.8$ and $53.4 \mathrm{mg}$ were absorbed. The characteristics of the absorption curves are shown in Text-fig. 1. For all dose levels used, the rate of absorption was rapid for the first 2 days and thereafter became a function of the 


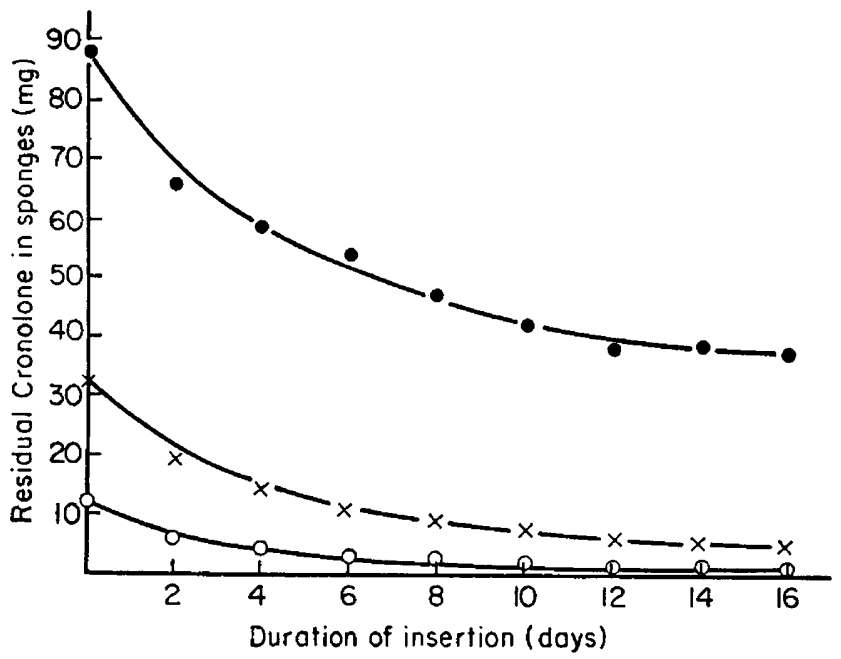

Text-pig. 1. Quantities of residual Cronolone in sponges after several durations of intravaginal insertion. Initial doses: $0,90 \mathrm{mg} ; \times, 30 \mathrm{mg} ; 0,10 \mathrm{mg}$.

amount present. Between Days 12 and 16, very little was absorbed, regardless of the intial dose.

\section{Oestrus}

Of the 480 ewes, $394(82 \cdot 1 \%)$ exhibited oestrus (Table 1$)$. There was a highly significant effect of progestagen treatment (treated, 87.5; untreated,

TABLE 1

INGIDENCE OF OESTRUS

\begin{tabular}{l|cccc|cc}
\hline \multirow{2}{*}{$\begin{array}{c}\text { Gonadotrophin } \\
\text { trealment }\end{array}$} & \multicolumn{4}{c|}{$\begin{array}{c}\text { Dose of progestagen }(\mathrm{mg}) \\
(n=60)\end{array}$} & \multicolumn{2}{c}{ Total } \\
\cline { 2 - 7 } & 0 & 10 & 30 & 90 & $\begin{array}{c}\text { No. } \\
(n=240)\end{array}$ & $\%$ \\
\hline PMSG & 38 & 49 & 55 & 57 & 199 & $82 \cdot 9$ \\
No PMSG & 41 & 46 & 50 & 58 & 195 & $81 \cdot 3$ \\
\hline Total-No. $(\mathrm{n}=120)$ & 79 & 95 & 105 & 115 & 394 & - \\
& 65.8 & 79.2 & 87.5 & $95 \cdot 8$ & - & $82 \cdot 1$ \\
\hline
\end{tabular}

Significance of treatment effects on percentage of ewes in oestrus:

Progestagen: 0 versus $\Sigma 10,30,90 \mathrm{mg} ; P<0.001$.

$10,30,90 \mathrm{mg}$ (linear); $P<0.001$.

Gonadotrophin: PMsG versus no PMSG; Not significant (NS).

$65.8 \%$ ) and a linear effect of dose of progestagen (10 mg, 79.2; $30 \mathrm{mg}, 87.5$; $90 \mathrm{mg}, 95.8 \% ; P<0.001$ ). PMSG had no effect and there was no interaction.

Twelve of the thirteen control animals examined at laparotomy had midcycle corpora lutea, indicating that they had ovulated without oestrus at the expected time.

The time of onset of oestrus was advanced by PMSG treatment $(P<0.01$; Text-fig. 2) and was delayed by increasing the dose of Cronolone $(P<0.001)$. 


\section{Ovaries}

Treatment with PMSG advanced the time of ovulation relative to the time of detection of oestrus $(P<0 \cdot 001)$. Whereas sixty-five of sixty-eight ewes subjected to laparotomy $24 \mathrm{hr}$ after insemination following PMSG had ovulated, only forty-

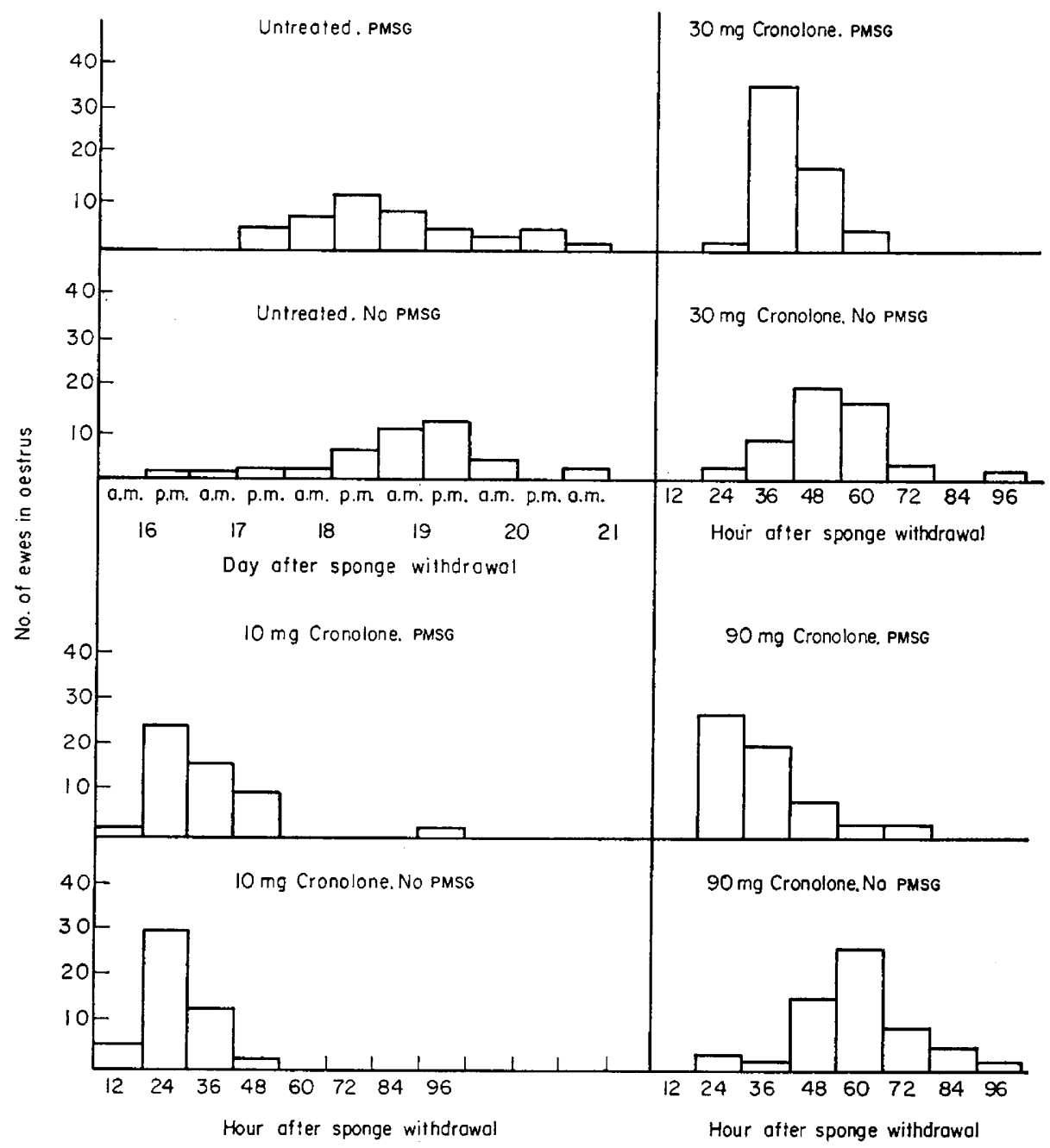

TEXT-FIG. 2. The time to onset of oestrus in untreated ewes and ewes treated with three doses of intravaginal progestagen. Dose of progestagen: Linear $P<0.001$. PMSG versus no PMSG: $P<0.01$.

seven of sixty-two not treated with PMSG had done so (Table 2). Increasing the dose of progestagen was associated with later ovulation relative to detection of oestrus $(P<0.05)$. There was no difference between the control and progestagen-treated ewes.

Table 3 summarizes the ovarian response to progestagen and PMSG treatments for all ewes subjected to laparotomy for the recovery of spermatozoa or ova. 
TABLE 2

NUMBER OF EWES WITH LARGE FOLLICLES OR WHICH HAD REGENTLY OVULATED WHEN EXAMINED FOR THE RECOVERY OF SPERMATOZOA 24 HR AFTER THE ONSET OF OESTRUS

\begin{tabular}{|c|c|c|c|c|c|c|c|}
\hline \multirow[b]{2}{*}{$\begin{array}{l}\text { Progestagen } \\
\text { treatment } \\
\quad(m g)\end{array}$} & \multicolumn{3}{|c|}{$P M S G$} & \multicolumn{3}{|c|}{ No PMSG } & \multirow[b]{2}{*}{$\begin{array}{c}\text { Total } \\
\% \\
\text { ovulated }\end{array}$} \\
\hline & $\begin{array}{l}\text { Total ewes } \\
\text { examined }\end{array}$ & $\begin{array}{l}\text { Recently } \\
\text { ovulated }\end{array}$ & $\begin{array}{l}\text { With large } \\
\text { follicles } \\
(>5 \mathrm{~mm})\end{array}$ & $\begin{array}{l}\text { Total ewes } \\
\text { examined }\end{array}$ & $\begin{array}{l}\text { Recently } \\
\text { ovulated }\end{array}$ & $\begin{array}{l}\text { With large } \\
\text { follicles } \\
(>5 \mathrm{~mm})\end{array}$ & \\
\hline $\begin{array}{r}0 \\
10 \\
30 \\
90\end{array}$ & $\begin{array}{l}14 \\
16 \\
18 \\
20\end{array}$ & $\begin{array}{l}13 \\
16 \\
18 \\
18\end{array}$ & $\begin{array}{l}1 \\
0 \\
0 \\
2\end{array}$ & $\begin{array}{l}14 \\
16 \\
14 \\
18\end{array}$ & $\begin{array}{r}10 \\
16 \\
8 \\
13\end{array}$ & $\begin{array}{l}4 \\
0 \\
6 \\
5\end{array}$ & $\begin{array}{r}82 \cdot 1 \\
100 \cdot 0 \\
81 \cdot 2 \\
81 \cdot 5\end{array}$ \\
\hline Total-No. & $\begin{array}{c}68 \\
100 \cdot 0\end{array}$ & $\begin{array}{l}65 \\
95 \cdot 7\end{array}$ & $\begin{array}{l}3 \\
4 \cdot 3\end{array}$ & $\begin{array}{l}62 \\
100 \cdot 0\end{array}$ & $\begin{array}{l}47 \\
75 \cdot 8\end{array}$ & $\begin{array}{l}15 \\
24 \cdot 2\end{array}$ & $\overline{86 \cdot 1}$ \\
\hline
\end{tabular}

Significance of treatment effects on percentage of ewes which had ovulated:

Progestagen: $\quad 0$ versus $\Sigma 10,30,90 \mathrm{mg}$; NS.

10 versus $\Sigma 30,90 \mathrm{mg} ; P<0 \cdot 05$.

30 versus $90 \mathrm{mg}$; NS.

Gonadotrophin: PMSG versus no PMSG $P<0.001$.

There was a linear trend towards a greater proportion of multiple ovulations with increasing doses of progestagen $(P<0 \cdot 10)$ and a highly significant increase with PMSG $(P<0.001)$.

TABLE 3

MEAN NUMBER OF OVULATIONS OR LARGE DEFINITIVE FOLLICLES ( $>5 \mathrm{MM}$ ) IN EWES EXAMINED AT LAPAROTOMY FOR REGOVERY OF SPERMATOZOA OR OVA 24 OR $48 \mathrm{HR}$ AFTER INSEMINATION

\begin{tabular}{c|cc|cc}
\hline & \multicolumn{2}{|c|}{$P M S G$} & \multicolumn{2}{|c}{ No PMSG } \\
\cline { 2 - 4 } $\begin{array}{c}\text { Progestagen } \\
\text { treatment } \\
(\mathrm{mg})\end{array}$ & $\begin{array}{c}\text { Mean no. } \\
\text { of ovulations } \\
\text { or definitive } \\
\text { follicles }\end{array}$ & $\begin{array}{c}\text { Mean no. } \\
\text { Total examined } \\
\text { exalal ewes }\end{array}$ & $\begin{array}{c}\text { Tor ovulations } \\
\text { or definitive } \\
\text { follicles }\end{array}$ \\
\hline 0 & 26 & 1.50 & 29 & 1.00 \\
10 & 31 & 1.26 & 31 & 1.03 \\
30 & 37 & 1.32 & 29 & 1.03 \\
90 & 39 & 1.51 & 36 & 1.08 \\
\hline Total & 133 & 1.40 & 125 & 1.03 \\
\hline
\end{tabular}

Significance of treatment effects on ovarian response:

Progestagen: $\quad 0$ versus $\Sigma 10,30,90 \mathrm{mg}$; NS. $10,30,90 \mathrm{mg}$ (linear) $0.05<P<0 \cdot 10$.

Gonadotrophin: PMSG versus no PMsG; $P<0.001$.

\section{Spermatozoa}

Counts were characterized by enormous variability. Spermatozoa were found in the flushings from only sixty-eight of the 130 ewes examined (Table 4). Fifty-three of 102 ewes treated with progestagen failed to yield spermatozoa as 
TABLE 4

ESTIMATED MEAN NUMBERS OF SPERMATOZOA RECOVERED FROM THE FALLOPIAN TUBES

\begin{tabular}{|c|c|c|c|c|}
\hline \multirow[b]{2}{*}{ Main effect } & \multicolumn{2}{|c|}{$\begin{array}{c}A \\
\text { No. of ewes }\end{array}$} & \multicolumn{2}{|c|}{$\begin{array}{c}B \\
\text { Mean no. of spermatozoa }\end{array}$} \\
\hline & Flushed & $\begin{array}{l}\text { Yielded } \\
\text { sperm. }\end{array}$ & Arithmetic & $\log$ \\
\hline $\begin{array}{c}\text { Progestagen (mg) } \\
0 \\
10 \\
30 \\
90\end{array}$ & $\begin{array}{l}28 \\
32 \\
32 \\
38\end{array}$ & $\begin{array}{l}19 \\
15 \\
15 \\
19\end{array}$ & $\begin{array}{r}2466 \\
632 \\
1900 \\
2329\end{array}$ & $\begin{array}{l}2 \cdot 08 \\
1 \cdot 44 \\
1 \cdot 52 \\
1 \cdot 54\end{array}$ \\
\hline $\begin{array}{r}\text { PMSO (i.u.) } \\
0 \\
500\end{array}$ & $\begin{array}{l}62 \\
68\end{array}$ & $\begin{array}{l}36 \\
32\end{array}$ & $\begin{array}{l}2264 \\
1893\end{array}$ & $\begin{array}{l}1.81 \\
1.46\end{array}$ \\
\hline Total & 130 & 68 & 2079 & - \\
\hline
\end{tabular}

Significance of treatment effects:

A

Progestagen: $\quad 0$ versus $\Sigma 10,30,90 \mathrm{mg} ; 0.05<P<0.10$. 0 versus $\Sigma 10,30,90 \mathrm{mg} ; P<0.05$.

10 versus $\Sigma 30,90 \mathrm{mg}$; NS. 10 versus $\Sigma 30,90 \mathrm{mg}$; NS.

30 versus $90 \mathrm{mg}$; NS. $\quad 30$ versus $90 \mathrm{mg}$; NS.

Gonadotrophin: PMSG versus no PMSG; NS. PMSG versus no PMSG; NS.

Data pooled for two tubes

compared with nine of twenty-eight untreated ewes $(52.0 \%$ versus $32.1 \%$; $P<0 \cdot 10)$, and the corrected (logarithmic) mean was less $(P<0 \cdot 05)$. PMSG had no effect.

Text-figure 3 shows the frequency distributions of ewes classed according to the

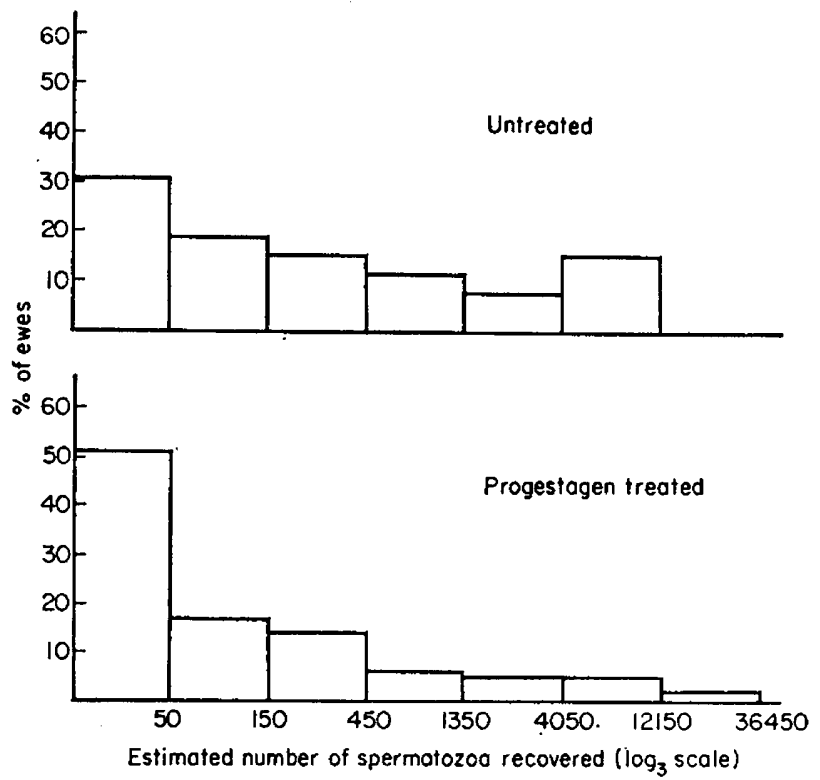

TeXT-FIG. 3. Distribution of numbers of spermatozoa recovered. 
estimated number of spermatozoa recovered $\left(\log _{3}\right.$ scale). These differ markedly from those published by Quinlivan \& Robinson (1967) in that there was a high proportion of ewes at the lower ends of the distributions and few at the upper ends.

The number of spermatozoa in the Fallopian tube proximal to the ovulating ovary was highly correlated with the number present in the other tube (for all ewes- $\mathrm{r}=0.73, P<0.01$; for all ewes with spermatozoa in both tubes- $\mathrm{r}=$ $0.75, P<0.01)$. The latter relationship is depicted in Text-fig. 4 .

Ova were found in the flushings from twenty-three of the 130 ewes. This low rate of recovery was due to flushing only $24 \mathrm{hr}$ after detection of oestrus. Gross

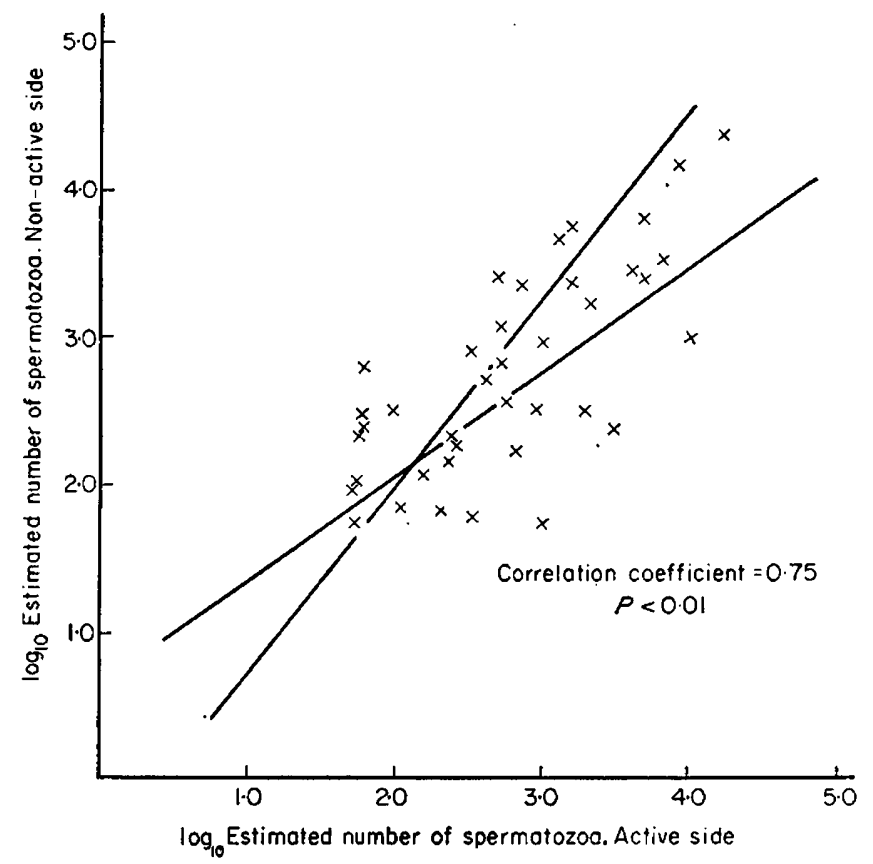

TEXT-FIG. 4. The relationship between estimated numbers of spermatozoa recovered from the Fallopian tube proximal to the active ovary and the other tube.

$x$, Only those animals with spermatozoa in both Fallopian tubes were used in the calculations.

morphological distortion made determination of the state of fertilization possible in twelve cases only. Nine were fertilized (seven early pronucleate and two with an expanded sperm head in the vitellus) but spermatozoa were found in only two of the nine flushings.

\section{Ova}

Table 5 shows the numbers of ewes which yielded ova in relation to the numbers flushed. Overall, $85 \cdot 2 \%$ yielded ova and there was significant heterogeneity between progestagen treatments $(P<0.05)$ and a significant linear increase in the percentage of ewes which yielded ova, with the increase in dose from 10 to $90 \mathrm{mg}(P<0 \cdot 01)$. Heterogeneity between progestagen treatments in 
TABle 5

NUMBER AND PERCENTAGE OF EWES FROM WHICH OVA WERE RECOVERED AND NUMBER AND PERGENTAGE OF THOSE WHICH WERE FERTILIZED

\begin{tabular}{|c|c|c|c|c|c|}
\hline \multirow[b]{2}{*}{ Main effect } & \multirow[b]{2}{*}{ No. of ewes } & \multicolumn{2}{|c|}{$\begin{array}{c}A \\
\text { Yielded ova }\end{array}$} & \multicolumn{2}{|c|}{$\begin{array}{c}B \\
\text { Yielded fertilized } \\
\text { ova }\end{array}$} \\
\hline & & No. & $\%$ & No. & $\% *$ \\
\hline $\begin{array}{c}\text { Progestagen }(\mathrm{mg}) \\
0 \\
10 \\
30 \\
90\end{array}$ & $\begin{array}{l}27 \\
30 \\
34 \\
37\end{array}$ & $\begin{array}{l}23 \\
21 \\
30 \\
35\end{array}$ & $\begin{array}{l}85 \cdot 2 \\
70 \cdot 0 \\
88 \cdot 2 \\
94 \cdot 6\end{array}$ & $\begin{array}{l}21 \\
13 \\
25 \\
26\end{array}$ & $\begin{array}{l}91 \cdot 3 \\
61 \cdot 9 \\
83 \cdot 3 \\
74 \cdot 3\end{array}$ \\
\hline $\begin{array}{r}\text { PMSG (i.u.) } 0 \\
500\end{array}$ & $\begin{array}{l}63 \\
65\end{array}$ & $\begin{array}{l}54 \\
55\end{array}$ & $\begin{array}{l}85 \cdot 7 \\
84 \cdot 6\end{array}$ & $\begin{array}{l}44 \\
41\end{array}$ & $\begin{array}{l}81 \cdot 5 \\
74 \cdot 5\end{array}$ \\
\hline Total & 128 & 109 & $85 \cdot 2$ & 85 & $78 \cdot 0$ \\
\hline
\end{tabular}

* Of ewes which yielded ova.

Significance of treatment effects: A

Progestagen: $\quad 0$ versus $\Sigma 10,30,90 \mathrm{mg}$; 0 versus $\Sigma 10,30,90 \mathrm{mg}$;

NS.

10 versus $\Sigma 30,90 \mathrm{mg}$; $P<0.01$.

30 versus $90 \mathrm{mg}$; NS.

Gonadotrophin: PMSG versus no PMSG; NS.

$$
P<0 \cdot 10 \text {. }
$$

10 versus $\Sigma 30,90 \mathrm{mg}$;

NS.

30 versus $90 \mathrm{mg}$; NS. PMSG versus no PMSG; NS.

\section{TABLE 6}

\begin{tabular}{|c|c|c|c|}
\hline \multicolumn{4}{|c|}{$\begin{array}{c}\text { DISTRIBUTION OF FERTILIZED OVA } \\
\text { ACCORDING TO THE NUMBER OF SPERM- } \\
\text { ATOZOA ON THE ZONA PELLUGIDA }\end{array}$} \\
\hline \multirow[b]{2}{*}{ Main effect } & \multicolumn{3}{|c|}{ No. of sperm. on zona } \\
\hline & 0 & 1 to 10 & $>10$ \\
\hline $\begin{array}{c}\text { Progestagen (mg) } \\
0 \\
10 \\
30 \\
90\end{array}$ & $\begin{array}{l}1 \\
2 \\
3 \\
9\end{array}$ & $\begin{array}{r}7 \\
3 \\
12 \\
15\end{array}$ & $\begin{array}{r}15 \\
7 \\
12 \\
9\end{array}$ \\
\hline $\begin{array}{r}\text { PMSG (i.u.) } \\
0 \\
500\end{array}$ & $\begin{array}{l}7 \\
8\end{array}$ & $\begin{array}{l}14 \\
23\end{array}$ & $\begin{array}{l}23 \\
20\end{array}$ \\
\hline Total & 15 & 37 & 43 \\
\hline
\end{tabular}

Significance of differences in distributions: Progestagen: $\quad 0 \mathrm{mg}$ versus $\Sigma 10,30,90 \mathrm{mg}$; $P<0.05$.

10 versus $\Sigma 30,90 \mathrm{mg}$; NS.

Gonadotrophin: PMSG versus no PMSG; NS.

Data are for numbers of fertilized ova recovered. In four cases, only the zona pellucida was recovered. Adherent spermatozoa indicated fertilization. No unfertilized ova had spermatozoa on the zona pellucida. 
the percentage of ewes fertilized approached significance $(P<0 \cdot 10)$, with the untreated ewes yielding the highest percentage of fertilized eggs and those treated with $10 \mathrm{mg}$ Cronolone the lowest $(91.3$ versus $61.9 \% ; P \fallingdotseq 0.05)$.

There was no effect of PMSG and no interaction.

Table 6 shows the distribution between treatments of fertilized ova classified according to the numbers of spermatozoa on the zona pellucida. The pattern was essentially similar to that obtained in the sperm counts. Progestagentreated ewes had a smaller proportion of fertilized ova with large numbers $(>10)$ of attached spermatozoa and a larger proportion with no attached spermatozoa than did untreated ewes $(P<0.05)$.

TABLE 7

DISTRIBUTION OF FERTILIZED OVA

ACCORDING TO THEIR GELL STAGE

\begin{tabular}{c|rrr}
\hline & \multicolumn{3}{|c}{ Cell stage } \\
\cline { 2 - 4 } \multicolumn{1}{c|}{ Main effect } & \multicolumn{1}{c}{1} & 2 & $>2$ \\
\hline Progestagen (mg) & & & \\
0 & 1 & 13 & 8 \\
10 & 1 & 6 & 5 \\
30 & 8 & 8 & 9 \\
90 & 13 & 10 & 9 \\
PMSG (i.u.) & & & \\
\multicolumn{1}{c|}{500} & 15 & 15 & 18 \\
Total & 22 & 13 \\
\hline
\end{tabular}

Significance of differences in distributions:

Progestagen: $\quad 0 \mathrm{mg}$ versus $\Sigma 10,30,90$ $\mathrm{mg} ; P<0.05$.

10 versus $\Sigma 30,90 \mathrm{mg}$; $P<0 \cdot 10$.

Gonadotrophin: PMSG versus no PMSG; $P<0.05$.

TABLE 8

NUMBER OF APPARENTLY 'ATYPICAL' OVA

\begin{tabular}{c|ccc}
\hline \multirow{2}{*}{$\begin{array}{c}\text { Progestagen } \\
\text { treatment } \\
(\mathrm{mg})\end{array}$} & \multicolumn{3}{|c}{ Classification of ova } \\
\cline { 2 - 4 } & Normal & Fragmented & $\begin{array}{c}\text { Scattered } \\
\text { chromatin }\end{array}$ \\
\hline 0 & 21 & 2 & 2 \\
10 & 21 & 2 & 0 \\
30 & 26 & 6 & 2 \\
90 & 39 & 6 & 1 \\
\hline Total & 107 & 16 & 5 \\
\hline
\end{tabular}

No significant differences between treatments. Data pooled for PMSG and no PMSG treatments. 
Table 7 shows a similar distribution according to cell stage. Ova recovered from progestagen-treated ewes were at an earlier stage of development than were those from untreated ewes $(P<0.05)$ and those from PMSG-treated ewes were at an earlier stage than were those from ewes not treated with PMSG

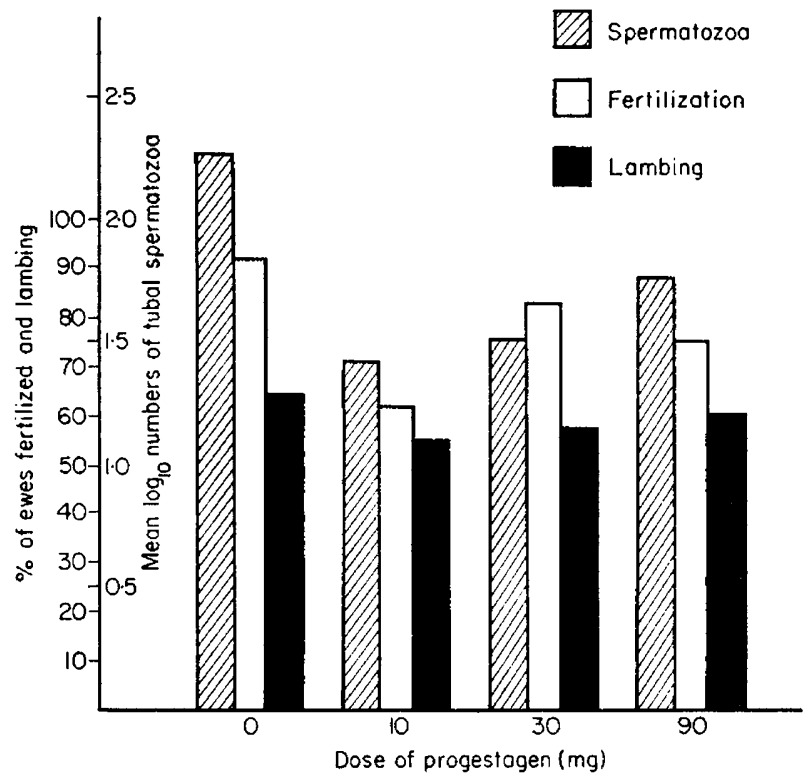

TEXT-FIG. 5. Relationship between treatment with progestagen and three parameters of fertility; numbers of spermatozoa in the Fallopian tubes, percentage of ewes fertilized and percentage of ewes lambing.

$(P<0 \cdot 05)$. With higher doses of progestagen, there was a tendency for ova to be at an earlier stage of development.

Table 8 shows that twenty-one of the 128 ova recovered were classed as 'atypical' and there were no significant differences between treatments.

\section{Lambing}

Table 9 presents lambing data. Overall, $58.5 \%$ of inseminated ewes lambed, $64.0 \%$ with no progestagen and $57 \cdot 1 \%$ for the pooled progestagen treatments (NS).

The incidence of multiple births was increased by progestagen treatment and by PMSG $(P<0 \cdot 05)$.

\section{Relationship between the three parameters of fertility}

Text-figure 5 shows the relationship between the data for numbers of spermatozoa, ewes with fertilized ova and lambing ewes. Analysis of the fertilization and lambing data (Table 10) shows a highly significant difference between the proportion of ewes fertilized and those which lambed $(P<0.01)$ and a difference between progestagen-treated and untreated ewes which approached significance $(P<0 \cdot 10)$. Treatment with $10 \mathrm{mg}$ Cronolone caused a marked drop in fertility; treatment with $30 \mathrm{mg}$ caused a less marked drop, 


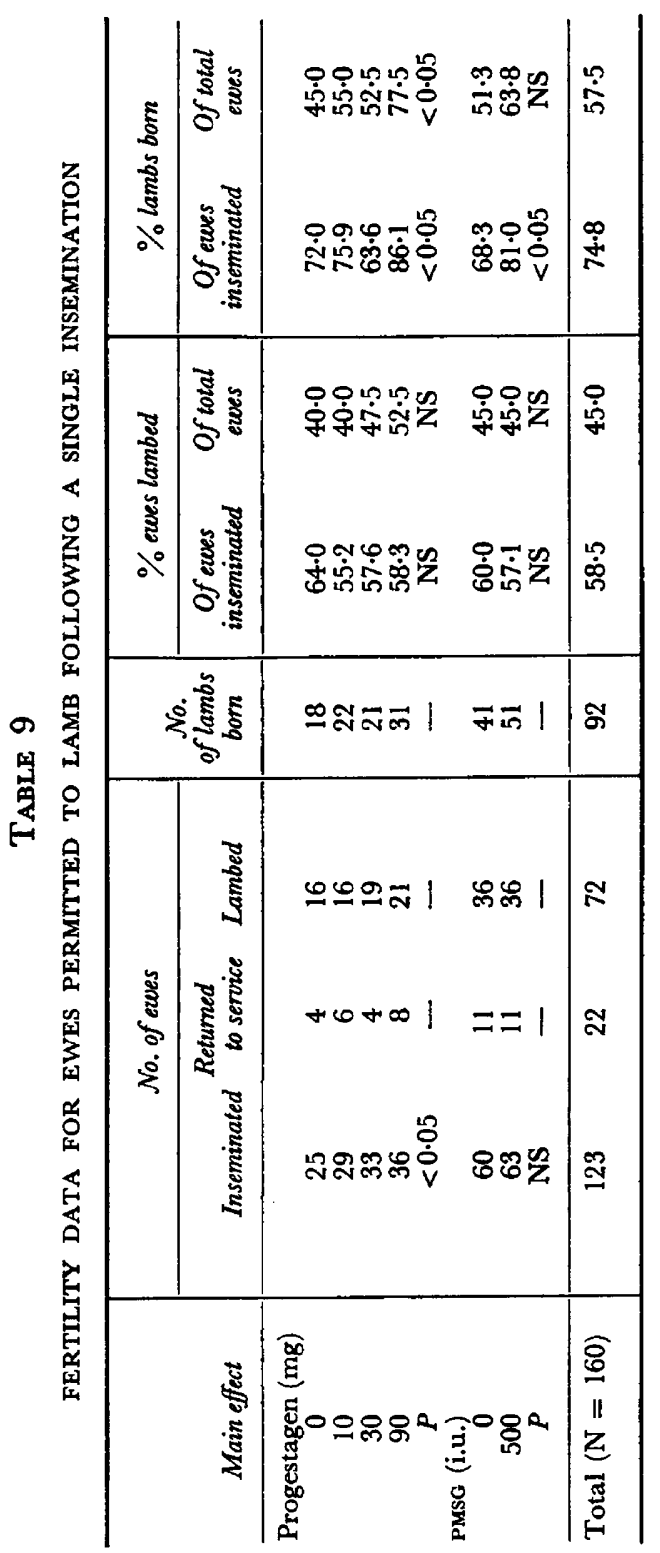




\section{TABLE 10}

TABLE OF $\chi^{2}$ FOR EWES GLASSED AS FERTILIZED AT 2 DAYS AND AT TERM, AS ILLUSTRATED IN TEXT-FIG. 5

\begin{tabular}{l|c|c|c}
\hline \multicolumn{1}{c|}{ Source of variation } & Degrees of freedom & $\chi^{2}$ & $\mathrm{P}$ \\
\cline { 2 - 3 } Stage of pregnancy & 1 & $8 \cdot 57$ & $<0 \cdot 01$ \\
Dose of progestagen $(\mathrm{mg})$ & $(3)$ & $(4 \cdot 36)$ & $\mathrm{NS}$ \\
0 versus $\Sigma 10,30,90$ & 1 & $2 \cdot 83$ & $<0 \cdot 10$ \\
10 versus $\Sigma 30,90$ & 1 & 1.42 & $\mathrm{NS}$ \\
30 versus 90 & 1 & $0 \cdot 11$ & $\mathrm{NS}$ \\
Interaction & 3 & $1 \cdot 60$ & $\mathrm{NS}$ \\
\hline
\end{tabular}

and there was no improvement with $90 \mathrm{mg}$. The relationship of fertility with number of spermatozoa recovered is also evident from the Text-figure.

\section{DISGUSSION}

The relationship between the fertility of the progestagen-treated ewes and the numbers of spermatozoa recoverable from the Fallopian tubes, and the altered pattern of sperm transport and survival in such ewes, has been well established by Quinlivan \& Robinson $(1967,1969)$. This is substantiated by the data in Tables 4, 5, 6 and 9 and illustrated in Text-fig. 5, which shows a good relationship between the mean numbers of spermatozoa recovered and the percentage of eggs fertilized and ewes which lamb. Thus, the ewes experiencing a normal oestrus yielded a mean of 2466 tubal spermatozoa and $91.3 \%$ of ova were fertilized. At the other extreme, ewes treated with sponges impregnated with $10 \mathrm{mg}$ Cronolone yielded a mean of 632 tubal spermatozoa and only $61.9 \%$ of ova were fertilized. The two remaining progestagen treatments were intermediate. Furthermore, whereas the fertilized ova of $65 \%$ of normal cyclic ewes had ten or more spermatozoa attached to the zona pellucida, only $39 \%$ of treated ewes had comparable numbers.

The lambing data follow a pattern which is similar to the fertilization data, although the magnitude of the differences is less and, unlike the latter, the lambing data fail to attain statistical significance. Again, the most and least successful treatment groups (no progestagen and $10 \mathrm{mg}$ Cronolone) were those from which the highest and lowest numbers of spermatozoa had been recovered, the other treatments being intermediate.

The most disturbing aspects of this investigation are the high proportion of ewes in which no spermatozoa could be found and the relatively small numbers in the remainder. There is no ready explanation and in view of the difference between these values and those obtained by Mattner (1963) and Quinlivan \& Robinson (1967, 1969), no conclusions can be drawn concerning the quantitative relationship between numbers of tubal spermatozoa and the chances of fertilization. It can be concluded that such a relationship does exist and that it is disturbed by inadequate progestagen treatment, such as is provided by sponges impregnated with $10 \mathrm{mg}$ Cronolone which release about $8 \mathrm{mg}$ over a 16-day period. This results in a significant reduction in the percentage of ova fertilized.

The recording of spermatozoa in only two of nine flushings from which fertilized ova were recovered was not surprising in view of the large number of 
animals in which no spermatozoa could be found. There are no reliable data concerning the numbers of tubal spermatozoa required for fertilization due to the dynamic nature of the situation. In this regard, data presented here are at variance with other published reports (Braden \& Austin, 1954; Quinlivan \& Robinson, 1967).

The incidence of oestrus in ewes not treated with progestagen was lower than that normally observed on the same property at the same time of the year. Drought conditions probably contributed to this; ewes were ovulating but were not exhibiting oestrus. The significant linear increase in incidence of oestrus with increase in dose of progestagen suggests that these 'silent' heats may be related to inadequate endogenous progesterone with consequent inadequate 'priming' of the ewe to respond to endogenous oestrogen, or to an inefficient control of the release of FSH with a concomitant inadequacy of oestrogen. In confirmation of this concept, the increasing ovarian response to injected PMSG was significantly associated with the increasing dose of progestagen.

The inefficiency of intravaginal sponges impregnated with insufficient progestagen is clearly shown. The difference between those impregnated with $10 \mathrm{mg}$ Cronolone on the one hand and those with 30 and $90 \mathrm{mg}$ on the other is apparent. Fewer ewes exhibited oestrus, fewer spermatozoa were recovered and fewer ova were fertilized. These differences were only vaguely shadowed in the lambing results, which incidentally were much better for the $10 \mathrm{mg}$ sponges than have been obtained previously (Robinson, 1967; Robinson \& Smith, 1967).

The observation that the numbers of spermatozoa found on the zona pellucida follow the same pattern as the numbers recovered by flushing the tubes extends the preliminary observation of Quinlivan \& Robinson (1967) and poses the possibility of using this as a practical measure of the effectiveness of sperm transport. The counting of spermatozoa is tedious so a more simple measure is needed. Further, if the data for number of spermatozoa on the zona were useful in this context, it should be possible to obtain data for sperm transport and fertilization in the same animal.

Another possibility is raised by the high correlation between the numbers of spermatozoa in the respective Fallopian tubes. The tube proximal to the nonactive ovary may be flushed for spermatozoa $24 \mathrm{hr}$ after insemination and the other flushed 24 to $48 \mathrm{hr}$ later for the recovery of ova, so providing data on numbers of spermatozoa and fertilization in the same animal.

Ova recovered from PMSG-treated ewes tended to be at an earlier stage of development than those from untreated ewes, despite their having been shed earlier. There is no apparent explanation for this phenomenon. Neither Moore et al. (1967) nor Quinlivan \& Robinson (1967) found any suggestion of differences in the cell stages of fertilized ova from progestagen-treated and untreated ewes. It is clear from the relatively low incidence of oestrus (and high incidence of 'silent' heats) in those ewes not treated with progestagen that ovarian activity was marginal.

A depression in the rate of recovery of ova in progestagen-treated ewes has previously been reported (Shelton \& Moore, 1967). The poor recovery of ova 
from ewes treated with $10 \mathrm{mg}$ Cronolone may be explained by a progesteroneoestrogen imbalance resulting from inadequate suppression of pituitary activity, causing either loss of ova to the uterus or failure of entry into the Fallopian tubes.

Quinlivan \& Robinson (1967) reported maximum numbers of spermatozoa in the Fallopian tubes of progestagen-treated ewes $36 \mathrm{hr}$ after insemination, and suggested the possibility of delayed fertilization and the consequent possibility of abnormal development of ova. In a later experiment (Quinlivan, 1967), approximately $20 \%$ of apparently fragmenting ova were recovered from progestagen-treated ewes. Our data show a similar percentage of 'atypical' ova (Table 8) but there is no suggestion of a higher incidence in progestagen-treated ewes. Further, Text-fig. 5 and the lack of interaction in Table 10 provide no evidence that embryonic mortality is greater in progestagen-treated than in untreated ewes. The overall discrepancy of $19.5 \%$ between ewes fertilized and ewes lambing lies well within published estimates of normal embryonic mortality (Robinson, 1957; Quinlivan, Martin, Taylor \& Cairney, 1966). Great caution is required in defining normality and abnormality in ova. Killeen (1969) has evidence that apparently fragmented ova will develop normally. Further, observations in this laboratory suggest that anucleate fragments in cleaved ova may simply be pieces of cytoplasm pinched off at the time of cell division.

It is concluded that treatment with Cronolone in intravaginal sponges reduces fertility at the first controlled oestrus by comparison with the second oestrus, by reducing the percentage of eggs which are fertilized as a result of impaired sperm transport and survival. There is no differential effect on the mortality of the fertilized eggs and the effect on sperm transport and consequent fertilization is most marked when the dose of progestagen is inadequate, as in sponges containing $10 \mathrm{mg}$ Cronolone which release about $8 \mathrm{mg}$ over a 16-day period.

\section{ACKNOWLEDGMENTS}

Grateful acknowledgment is made to the Trustees of the McCaughey Memorial Institute, Jerilderie, N.S.W., for making sheep available and also certain facilities, and to Dr N. W. Moore and Dr I. D. Killeen for experimental assistance.

Financial support was provided by G. D. Searle (Aust.) Ltd and the Australian Research Grants Committee. One of the authors (A.J.A.) was the recipient of an Australian Commonwealth Scholarship.

\section{REFERENCES}

BrADEN, A. W. H. \& Austin, C. R. (1954) The number of sperms about the eggs of mammals and its significance for normal fertilisation. Aust. 7. biol. Sci. 7, 543 .

Dzruk, P. J. (1965) Timing of maturation and fertilisation of the sheep egg. Anat. Rec. 153, 211.

EMmens, G. W. \& Robinson, T. J. (1962) In: The Semen of Animals and Artificial Insemination, pp. 205-251. Ed. J. P. Maule. C.A.B. Tech. Comm. No. 15.

Hackett, A. J. \& Macpherson, J. W. (1965) Some staining procedures for spermatozoa. A review. Can. vet. F. 6, 55 .

Hunter, G. L., Adams, C. E. \& Rowson, L. E. A. (1955) Inter-breed ovum transfer in sheep. $\mathcal{F}$. agric. Sci., Camb. 46, 143. 
KILLEEN, I. D. (1969) Studies on fertilisation and early development of the ovine ovum. Ph.D. thesis, University of Sydney.

Matrner, P. E. (1963) Spermatozoa in the genital tract of the ewe. II. Distribution after coitus. Aust. 7. biol. Sci. 16, 688.

Moore, N. W., Quinurvan, T. D., Robinson, T.J. \& Smith, J. F. (1967) The fertilization of ova following natural mating and artificial insemination after withdrawal of SC-9880 impregnated intravaginal sponges from cyclic Merino ewes. In: The Control of the Ovarian Gycle in the Sheep, p. 169. Ed. T. J. Robinson. Sydney University Press.

Morgan, J., LAck, R. E. \& Robinson, T. J. (1967) The rate of absorption of SC-9880 from impregnated sponges inserted intravaginally in cyclic crossbred ewes. In: The Control of the Ovarian Cycle in the Sheep, p. 195. Ed. T. J. Robinson. Sydney University Press.

Quinlivan, T. D. (1967) Studies in ovine reproduction. Ph.D. thesis, University of Sydney.

Quinlivan, T. D., Martin, C. A., Taylor, W. L. \& Cairney, F. M. (1966) Estimates of pre- and perinatal mortality in the New Zealand Romney Marsh ewe. I. Pre- and perinatal mortality in those ewes that conceived to one service. 7. Reprod. Fert. 11, 379.

Quinlivan, T. D. \& Robinson, T. J. (1967) The number of spermatozoa in the Fallopian tubes of ewes at intervals after artificial insemination following withdrawal of SC-9880 impregnated intravaginal sponges. In: The Control of the Ovarian Cycle in the Sheep, p. 177. Ed. T. J. Robinson. Sydney University Press.

Quinlivan, T. D. \& Robinson, T. J. (1969) Numbers of spermatozoa in the genital tract after artificial insemination of progestagen-treated ewes. 7. Reprod. Fert. 19, 73.

RAdFoRd, H. M., Watson, R. H. \& Wood, G. F. (1960) A crayon and associated harness for the detection of mating under field conditions. Aust. vet. 7. 36, 57 .

Robinson, T. J. (1957) Pregnancy. In: Progress in the Physiology of Farm Animals, p. 793. Ed. J. Hammond. Butterworths, London.

Robinson, T. J. (1967) Conclusions. In: The Control of the Ovarian Gycle in the Sheep, p. 227. Ed. T. J Robinson. Sydney University Press.

Robinson, T. J., Quinlivan, T. D. \& Baxter, C. (1968) The relationship between dose of progestagen and method of preparation of intravaginal sponges on their effectiveness for the control of ovulation in the ewe. . Reprod. Fert. 17, 471.

Robinson, T. J., Salamon, S., Moore, N. W. \& Smrth, J. F. (1967) The evaluation of SC-9880-impregnated intravaginal sponges for the synchronization of oestrus for large scale artificial insemination of Merino ewes in summer and autumn. In: The Control of the Ovarian Cycle in the Sheep, p. 208. Ed. T. J. Robinson. Sydney University Press.

Robinson, T. J. \& Smith, J. F. (1967) The time of ovulation after withdrawal of SC-9880 impregnated intravaginal sponges from cyclic Merino ewes. In: The Control of the Ovarian Cycle in the Sheep, p. 158. Ed. T. J. Robinson. Sydney University Press.

Shelton, J. N. \& Moore, N. W. (1967) The evaluation of alternative methods of administration of progestagens in the entire cyclic ewe. In: The Control of the Ovarian Gycle in the Sheep, p. 59. Ed. T. J. Robinson. Sydney University Press. 